\title{
Gender Redistribution of Roles and Phony Heroes in Ossidinge (Cameroon) during the First World War, 1914- 1916
}

\author{
Thomas Etamba Eta, Nixon Kahjum Takor*, Ph.D \\ Department of History and Archaeology, Faculty of Arts, The University of Bamenda, Cameroon
}

*Corresponding Author: Dr. Nixon Kahjum Takor, Department of History and Archaeology, Faculty of Arts, The University of Bamenda, Cameroon

\begin{abstract}
The First World War that broke out in August 1914 produced categories of rippling effects in different war theatres around the globe, especially Cameroon which was a German strategic Protectorate. The extension of the war to Cameroon by the combined Anglo-French contingent in many respects besides its upsetting toll on lives and property engendered a scene of new social dynamics and invidious power relations. This phenomenon was particularly common in Ossidinge, a German administrative outpost which became a major war playhouse in the Cameroon phase of the war. It is in this matrix that the article examines the major social developments associated with mutations in the gender distribution of labour and the emergence of phony heroes which altered the pre-war society. From the basis of data gleaned and qualitatively interpreted from primary and secondary sources, the study establishes that the heavy involvement of men in the war had as opportunity cost the forestallment of economic activities notably, agriculture. Faced with this challenge, women stepped up to fill the vacuum and by extension became the new economic entrepreneurs with privilege access to wealth accumulation. In the same context, some of the men who fought in the war for the Germans or the British developed prey-tactics and took advantage of the war-scare to lord authority and exploit their own people.
\end{abstract}

Keywords: Cameroon, Gender, First World War, Redistribution, Phony Heroes, Ossidinge.

\section{INTRODUCTION}

On 4 August 1914, the Sarajevo contention scaled out of proportion when Britain declared war on Germany following the violation of the neutrality of Belgium which had been guaranteed at the Treaty of London in 1839. At the time the First World escalated in Europe, Cameroon was incontestably a German Protectorate annexed way back in July 1884.By 1913, German rule had been implanted in the territory through punitive means, especially forced labour and corporal punishment. The German administrative control gave them the leverage to carry on large scale agricultural development and promote some alien social activities like western education. These economic and social projects were interrupted by the outbreak of the First World War in Europe. The news of the outbreak of the war was received in Cameroon with mixed feelings. This emanated from the fact that there were some Cameroonians who did not cherish German rule and thus welcomed the war as a means to put an end to what they considered as martial rule. ${ }^{1}$ On 5 August 1914, one day after Britain declared war on Germany and two days after Germany declared war on France, the British government authorised the formation of a joint naval and military committee to consider naval and military operations in foreign territories. ${ }^{2}$ The committee known as the Offensive Sub-Committee of the Committee of Imperial Defense (OSCCID) and chaired by Admiral Sir Henry Jackson was assigned the task to launch operations against strategic German overseas possessions. ${ }^{3}$

The decision to extend the war to Cameroon gained momentum when a British ship-master reported to the authorities that the Germans had seized the Spanish wireless transmitter station at Fernando Po

\footnotetext{
${ }^{1}$ W.N.O Effiom, 94 years, former Grand Chancellor of the National Order of Valour and one-time Speaker of the West Cameroon House of Assembly, 20 December 2016.

${ }^{2}$ David Stevenson, 1914-1918: The History of the First World War (London: Penguin Books, 2005),73-74.

${ }^{3}$ Sir Joseph Cawston, \& Sons Limited, The War of 1914-1916. The Belgian Campaigns, In the Cameroons and in German East Africa (London: Free press, 1917),11.
} 
and that the German cruiser SMS Dresden was expected in Douala. ${ }^{4}$ These reports proved to bear no evidence but prompted the Admiralty to order the British cruiser Cumberland to proceed to the Cameroons River to investigate this information. ${ }^{5}$ The decision made by the Allies to fight the Germans both on home and away grounds especially in Cameroon appeared to be a whole episode of bewilderment to the Germans. ${ }^{6}$ This was because in their colonial task in Cameroon, the Germans made little or no effort to draft and sincerely drill the indigenes in the techniques of modern warfare. To this, can be added the fact that during the reign of Jesko von Puttkammer, the third German Governor in Cameroon, indigenes were sufficiently irritated and humiliated by the Germans through flogging, forced labour, overbearing taxation and other social ills so much that any power in war against the Germans in Cameroon could win their support with little wooing. ${ }^{7}$

The Germans did not want the war to be extended to Africa and as such put in place measures to prevent its spread. The paramount reason for this German action was unambiguous, they wanted to avoid a situation where Europeans would scandalise and disgrace themselves in front of the local population by fighting and killing one another. ${ }^{8}$ However, the forces in Britain militating in favour of involving the German colony of Cameroon in the war were pressing. The most important reason why the British extended the war to Cameroon was to take control of Douala which was the chief port and commercial nucleus of German Kamerun. ${ }^{9}$ It was also the base of a powerful wireless station which had direct contact with Kamina in Togoland and which the Germans used to monitor British shipping in the Atlantic. It therefore posed a potential threat to British trade and other naval operations in the Atlantic. This made Douala the most precious piece of Cameroon territory and partly explains why it bulked so large in the Anglo-French negotiations about the political future of Cameroon at the end of the war in the territory in $1916 .{ }^{10}$

To these substantial military and strategic assets must be added an economic one. With its railway and port, Douala's economic potential was considerable. Its nearness to the plantations in Victoria, Tiko and Buea mountain districts greatly enhanced this economic value. ${ }^{11}$ It is important to note that, these plantation districts were also close to the strategic Nigerian border and could not have escaped the notice of the British. In the British plan to capture Douala, they envisaged a possibility of passing through Ossidinge. ${ }^{12}$ For this reason, the British moved some of their forces and arsenal to Ossidinge and the resultant effect was the clash with the Germans at Nsanaragati on 23 August 1914. After the battle of Nsanaragati, the British and the Germans intensified mobilisation in Ossidinge making it an exhilarating war theatre with inestimable socio-economic and political effects.

\section{Indigenous Participation in the Ossidinge Phase of the War}

Ossidinge constituted one of the twenty-six districts in German Kamerun, it was made up of polities from different ethnic backgrounds. The polities were located between latitude $5^{\circ} 27^{1}$ and $5^{\circ} 56^{1}$ North of the Equator and longitudes $9^{\circ} 11^{1}$ and $9^{\circ} 51$ East of the Greenwich Meridian. The total surface area occupied by the District was 9,550 sqkm. ${ }^{13}$ In 1916 , it had a population of about 40,000inhabitants. ${ }^{14}$ The area occupied by Ossidinge is coterminous to Manyu, Lebialem and Widikum (part of Momo

\footnotetext{
${ }^{4}$ Ibid.

${ }^{5}$ Peter J. Yearwood. "In a Casual Way with a Blue Pencil: British Policy and the Partition of Kamerun, 19141919” Canadian Journal of African Studies. Vol. 27 No. 2, 1993, pp 218-244.

${ }^{6}$ Effiom, Mamfe, 20 December 2016.

${ }^{7}$ TabeTando Ndip Nso, HRH. 67 years, king of the Bachuo-Ntai kingdom, Douala, 11 January 2018.

${ }^{8}$ C. Weladji "The Cameroon-Nigeria Border 1914 and after" (5 $5^{\text {th }}$ and last instalment), ABBIA. No. 38-39-40 (May 1982): 213.

${ }^{9}$ F. J Moberly, Military Operations, Togoland and the Cameroons, 1914-1916 (Uckfield East Sussex: The Naval and Military Press, 2004), 66.

${ }^{10}$ Michael Crowder, "The First World War and its Consequences" in Adu Boahen, ed., General History of Africa,Vol III: Africa Under Colonial Domination 1880-1935. (California: Heinemann, 1985), 101.

${ }^{11}$ Edmond Bond, "The Conquest of Cameroon" Contemporary Review- 109 (1916): 620-27.

${ }^{12}$ Effiom, interview byEtamba, Mamfe, 20 December 2016

${ }^{13}$ J.T. Tabe "Chieftaincy Succession in the Banyang and Ejagham Tribes of Manyu Division Cameroon, 1961 -

2002" (Diplomed'Etudes Approfondies in History, University of Yaounde, 2007), 64.

${ }^{14}$ M. Tambi Eyongetah, Brain Robert and Palmer Robin, A History of Cameroon

(London: Longman, 1987),65.
} 
Division) in contemporary Cameroon. This paper however, is limited to the portion of Ossidinge inhabited by the Banyang and Ejagham ethnic groups, the areas coterminous to Mamfe, Eyumojock and Upper Banyang Sub Divisions of Manyu Division. ${ }^{15}$

German and Allied War strategies in Ossidinge consisted of making use of the indigenous people and the available resources on the ground. Comparatively, the Germans made more use of the people and their resources than the British. ${ }^{16}$ The Germans understood that their African colonies were surrounded by hostile Allied territories. For example, Ossidinge shared a common border with Nigeria which was not only a British colony but also a base for British forces in West Africa. In addition, the navigable Cross River made Ossidinge permeable to Allied naval supremacy. ${ }^{17}$ For this reason, the Germans kept a close watch on the area through constant patrols.

It is cardinal to point out that the German military presence in this area could be traced back to 1901 when a military post was opened in Tinto and then in Agborkem and Nsanakang. ${ }^{18}$ On the eve of the start of World War One in Ossidinge, the Germans who were installed in the area had a small force and could equally count on the population which they could coerce to fight on their behalf. The German force in Ossidinge was estimated at six officers, that is commissioned and non-commissioned and 175 soldiers mostly from Ossidinge. ${ }^{19}$ Thus, without actually being aware that the war would reach Ossidinge, the Germans, notwithstanding, could fight even though not for a long period against the British. ${ }^{20}$ When the war was extended to Cameroon, the Germans in a hurry decided to persuade and conscript the indigenes in their colonial army. ${ }^{21}$

The German administration convinced the people of Ossidinge to fight for them by offering gifts like salt, singlet, caps, mirrors and money. In some instances, the Germans promised to hand over to the polities that supported them sovereign control over those that sided with the enemy. This was the case of Bessongabang which in exchange of their support, was promised suzerainty over communities like Bessinge, Ntenako and Ndekwai. ${ }^{22}$ However lofty this promise was, it was not mutualised because, Bessongabang did not exude exemplary loyaltyto the Germans in the war agenda. The Allies on their part informed their various field commanders to maintain cordial relations with the local population and to enlist the support of the people because they were aware of the strained relations that existed between the Germans and most of the communities in Ossidinge. The villages of Ejwengang, Sabes, Tinto, Kembong, Besongabang, Mfainchang, Defang, Kembong and Ebeagwa that were resentful of the German policies, especially forced labour, fled to meet the advancing Allied columns who first came from Nigeria. ${ }^{23}$ They were prepared to offer whatever aid they could to the Allies. In return, the Allies led by the British, gave gifts of glasses, overcoat, hats, "whisky" and majestic staves to the people of Ossidinge. ${ }^{24}$

The reaction towards war in Ossidinge and the transition from peace to wartime differed from one polity to the other. Many people in Ossidinge saw the magnitude of the war cloud on the horizon and were deeply anxious about the gravity of the conflict that Germany and her empire had entered into, thereby making Ossidinge a major war theatre. Ossidinge communities experienced an intricate range of diverse responses to the spread of the war to their natural habitat. ${ }^{25}$ The indigenes participated in the war as soldiers, intelligence personnel, porters, informants and river navigators. The participation of the male folk in the war unleashed a social transmutation which hitherto was not experienced in the Ossidinge community.

\footnotetext{
${ }^{15}$ Michels, Imagined Power Contested, 186.

16 Ibid.

${ }^{17}$ Crowder "The First World War and its Consequences", 285.

${ }^{18}$ Stephanie Michels, Imagined Power Contested: Germans and Africans in the Upper Cross River Area of Cameroon 1887-1915 (Koln: Transaction Publishers, 2004), 161.

${ }^{19}$ Ibid., 268.

${ }^{20}$ Effiom, Mamfe, 20 December 2018.

${ }^{21}$ Kennedy EyongTabe," Kamerunian Participation in the First World War 1914-1916"(MA Thesis, University of Buea, 2001),43.

${ }^{22}$ Ibid

${ }^{23}$ Effiom, Mamfe, 20 September 2016.

${ }^{24}$ Stolz, "Manuscripts On My Long Stay in Besongabang" 17.

${ }^{25}$ Ibid.
} 


\section{Gender And Military Service}

The conscription of men from the ages of eighteen to forty-five in 1914 was a challenge to the established gender division of labour in the polities of Ossidinge. It presaged consideration for alternative sources of manpower for some traditional or local industries in Ossidinge. ${ }^{26}$ The process of substituting male labour with female labour was facilitated greatly by the conscription of men in the war program. ${ }^{27}$ In line with this, Grayzel suggests that the female worker became emblematic of the wartime mobilisation of women and of the alleged transformation of gender roles and even identities. $^{28}$

The absence of men in the palm oil, mat and basket industries and the fact that there was a remarkable drop in domestic income in Ossidinge made the women to deviate from traditionally defined roles. Before the war, women were involved in the growing of food crops such as cassava, cocoyams, beans, pepper and vegetables of all types. Women were not involved in the palm oil industry but the dynamics of war made them to fill this widening gap. This gave added impetus and importance to women in Ossidinge to launch a concerted campaign to exhort and educate the various polities of the necessity for women to replace men in the task which they used to do ${ }^{29}$ This endeavour was made concrete during a meeting in Ntotokonok, Besongabang in 1916 in which women were encouraged to fit into the chores that were previously handled by men. In their discussions, they stated that the disaster that befell them during the Mpawmanku war would be repeated if they did not work hard to replace their husbands who fought in the white man's war. ${ }^{30}$

Correspondingly in 1915, women of Egbekaw met to discuss similar issues. In attendance were women from Bachuo-Ntai, Nchang and Egbekaw; these three villages made up the Nfawtek clan. The women resolved that they should assume the duties of the men who were recruited as fighters, porters and informants. They encouraged the young ladies to work so that palm nuts should not get rotten. ${ }^{31}$ However, hesitation continued to be prevalent among some women in the villages who considered the new tasks very tedious. In the Ngonaya area where most of the villages had a good number of their able-bodied male around, the men were apprehensive about the contribution that women could make in the palm oil industry and as a result did not give the women the opportunity to participate in the palm oil industry which was a lucrative business. ${ }^{32}$

The promotion of female labour in agriculture was a subject which was an integral thread in the discourses of patriotism expressed not solely by notable women of the various polities in Ossidinge but also by other members of Ossidinge elite. ${ }^{33}$ Despite the rhetoric which emphasised the success of female endeavours in Ossidinge, it was evident that these accomplishments did not alter the perceptions of some men towards the gendered division of work. ${ }^{34}$ Instead, the utilisation of women labour in some polities in Ossidinge was understood by some men in other polities as a threat to their self-esteem. This was so because women started accumulating personal wealth which was not the case before the war.

The absence of men as a result of their conscription into the military force inevitably made women to become the new custodians of the family treasury. ${ }^{35}$ After the war, the men who returned met their wives performing male inclined functions. The change was enormous and, according to Karl Stolz,

\footnotetext{
${ }^{26}$ ABM, Karl Stolz, Jahresbericht Ossing, 1914.File No.E-2-14.

${ }^{27}$ Nicolette F. Gullace, The Blood of Our Sons: Men, Women and the Renegotiation of British citizenship during the Great War (New York: Palgrave Macmillan, 2002), 159.

${ }^{28}$ Susan R. Grayzels Women's Identities at War.Gender, Motherhood, and Politics in Britain and France during the First World War (Chapel Hill: The University of North Carolina Press, 1999), 267.

${ }^{29}$ Micheal EtchuTarkang, 77 years, farmer, Mamfe, 17 December 2016.

${ }^{30}$ The Mpawmanku wars refer to the insurrection that occurred among a group of Keyaka, Anyang, Basho and Manta villages and resulted in the destruction of the German station at Agborkem, leaving houses ruined and villages deserted. Limburg, the officer in charge of the Mamfe District was murdered and the station was overrun and looted; ABM, Karl Stolz, "Without Title, 1915",File No. E-2-15.

${ }^{31}$ ABM, Pauline Stolz, 01: 06: 1915 "Without Title" File No.E-2-14.

${ }^{32}$ Ibid.

${ }^{33} \mathrm{Ibid}$.

${ }^{34} \mathrm{Ibid}$.

${ }^{35}$ Cecilia, Mangyep, 64 years, teacher, Mamfe, 19 December 2016.
}

International Journal of History and Cultural Studies (IJHCS) 
"some men came back from the war just to find out that it was a force that had propelled the women to riches" ${ }^{36}$ Some marriages were destroyed by the war because women did not want to surrender their newly acquired wealth and status to their husbands. With women now in possession of wealth, they began clamouring for more rights in their community. ${ }^{37}$ For instance in 1915, Bessongabang women demanded the right to create a women's institution which could be their own version of the Ekpe. ${ }^{38}$ But, this was vehemently rejected. ${ }^{39} \mathrm{~A}$ planned meeting by the women to express their grievances in front of the chief's residence did not hold because of the small number of women who showed up. ${ }^{40}$ Having lost economic power, some of the men that got embroiled in the war covetously exploited the war-scare and established notoriety as phony entrepreneurs.

\section{The War Situation and Development of Phony Entrepreneurs}

The period of the First World War in Ossidinge was marked by some dysfunctional attitudes. This was peculiar after the last battle at Nfainchang. ${ }^{41}$ Following the German retreat to the Bamenda Grassfields, a strange attitude developed whereby some indigenous war-actors began to arrogate inestimable power over wealth and people. Acting under the guise of appropriated German or British authority, some men contoured avenues to gain material and immaterial wealth and to grasp the opportunity of these new indeterminate areas of power to become the new influential power surrogates. ${ }^{42}$

Those who took powers into their hands were mostly ex-German soldiers who had returned to their villages after the war. Cases of arrogation of power by ex-British soldiers were infrequent. The reason for this could be attributed to the fact that the British gave holistic training to their recruits. This made them more disciplined and well behaved than those of the Germans. ${ }^{43}$ In some polities, even those who participated in the war as porters claimed the title of "German soldier". ${ }^{44}$ Between 1915 and 1916, it was difficult to determine who was an ex-German soldier or not. This was due to the fact that some of the indigenes who participated in the war did not make any distinction as to the role they played. ${ }^{45}$ They were collectively referred to as "German soldiers". It is believed that this was done deliberately because ex-soldiers were feared and admired more than those who performed other functions during the war. ${ }^{46}$

By the time they returned home a good number of them had not made the money they expected from the war. For this reason and others, these "German soldiers" arrogated powers to themselves. In some villages they took advantage of the fact that the chiefs were killed by the Germans or the British to cause havoc. The atrocities of these "German soldiers", though not very recurrent in Ossidinge, were noticeable in some polities during the period 1915-1916. They put on their wartime outfits and moved from one household to the other and collected fowls, goats and foodstuffs. ${ }^{47}$ They made themselves rich at the expense of their own people. An example of the situation mentioned above was reported in the village of Ayukaba. ${ }^{48}$ In an interview conducted by Peter Arrey Mbu in 1997 with OjongNcho, the son of Eta Awo Ncho, a "German soldier" in Ayukaba, he testified that:

\footnotetext{
${ }^{36}$ Karl Stolz, "Without Title",15.

${ }^{37}$ Ma Emilia Ayuk, 65 years, farmer, Ewelle, 18 December 2016.

${ }^{38}$ Ekpe is a prestigious male institution. It is named after the leopard. The fear that the people had for the

Leopard made them to name this institution after this large wild cat. It was the most influential judicial, political, social and cultural institution among the people of Ossidinge.

${ }^{39}$ Paulin Stolz," Without Title", 18.

${ }^{40}$ Ibid.

${ }^{41}$ The battle of Nfainchang was fought on 5 May 1915. It was the last battle of the First World War in Ossidinge.

${ }^{42}$ Effiom, Mamfe, 20 September 2016.

${ }^{43}$ Michels,Imagined Power Contested, 354.

${ }^{44}$ MansfeldAyukeba, 80 years, retired trader, interview by Etamba, Mamfe ,13 December 2016.

${ }^{45}$ Ibid.

${ }^{46} \mathrm{Ibid}$

${ }^{47}$ BAB, R1001/4313:81-83, Expeditionen Ossidinge.

${ }^{48}$ Victor Tarkang Etchu, "Politics and Power in the Ejagham Clan of Manyu Division. The Case of the Ngonaya People, 1910- 1984” (Post Graduate Teachers Diploma (DI.P.E.S.II), Dissertation, University of Yaounde I, 1999), 66.
} 
The returning German soldiers out of frustration of not being able to raise even money for dowry became very aggressive and brutal. My father recounted that as young and naïve as they were, they thought that since they had the German uniforms, they could act on behalf of the Germans. That they went around and asked the people to give them goats and other food stuffs or if not they will be arrested and taken to Mamfe. In the early days of the German departure my father and some others took advantage of their German uniforms to extort different items from the people. ${ }^{49}$

It is obvious that the war was a force that, in some circumstances created disorder and paved the way for extortionists to perpetrate acts of injustice. The indigenes who worked for the Germans used their proximity as a source of prestige and proof that they still had contact with the Germans. In order to falsely reassure the people of their ties with the Germans, some of the ex-German soldiers went to Nsanakang to pay homage at the graves of the German soldiers whom they said were their friends. ${ }^{50}$

The people did not know the positions of the Germans, some thought they were still hiding in the bush and sending their representatives to exploit them; others believed they were no longer in the area. ${ }^{51}$ It was only towards the end of 1916 that the people actually knew that the Germans were no longer in control. During this period of confusion, the so called "German soldiers" filled the gap and enriched themselves. ${ }^{52}$ According to Tabi Nkonghonyor "a new order set in, where the village heads or their representatives were scared of the "German soldiers". 53

In Nsanaragati, Egemene who worked for the Germans as a carrier and domestic aide in Nsanakang and Agborkem escaped to Ikom in British Nigeria during the war. He returned in 1915 and was ready to reassert German influence. He was involved in a series of malpractices which hinged more on his close collaboration with the Germans before and during the war. ${ }^{54}$ In one of his outings as a close aide to the Germans, he compelled some people of Nsanaragati to pay their tax money to him. Dressed in his brown uniform, he moved round the village aided by two young men asking the people to pay their taxes in kind or in German Mark. ${ }^{55}$ He extorted money from the people and made them to believe that he was assigned to do so. Effiom affirms that:

The First World War made some indigenes to take advantage of their relationship with the

Germans to exploit the people. In my native Nsan (Nsanaragati) there was the case of Otang

Egemene who collected money from the people on the ground that he had been assigned to do

so. He simply used the name of the Germans to milk his people. He collected fowls, goats and

other foodstuff from those who did not have the money to pay. ${ }^{56}$

The misuse of German power in Nsanaragati by Egemene was only exposed in 1916 after he had, on several instances extorted money from the people. It is generally believed that the ex-German soldiers and their collaborators planned to do so since they did not make substantial benefits from the War. ${ }^{57}$

Similarly, in Ebeagwa, it was estimated that the amount of money that was extorted by Ashu Nkem as taxes meant for the German colonial administration stood at 10 Marks in $1916 .{ }^{58}$ His peculiarity was that he rejected taxes in kind, something which the people had been used to. His physical appearance was imposing and the fact that he had left for the war at Nfainchang made the people to believe that he was an agent of the Germans. These fake surrogate tactics however did not sail smoothly in all the attempts. The case of Ashu Nkem is illustrative. On a particular tax drive in Ebeagwa, there was a confrontation between his team and his kinsmen who had started suspecting him of taking advantage of German power to extort money from them in the form of tax. ${ }^{59}$ They were chased out of Ebeagwa and in the course he was severely wounded.

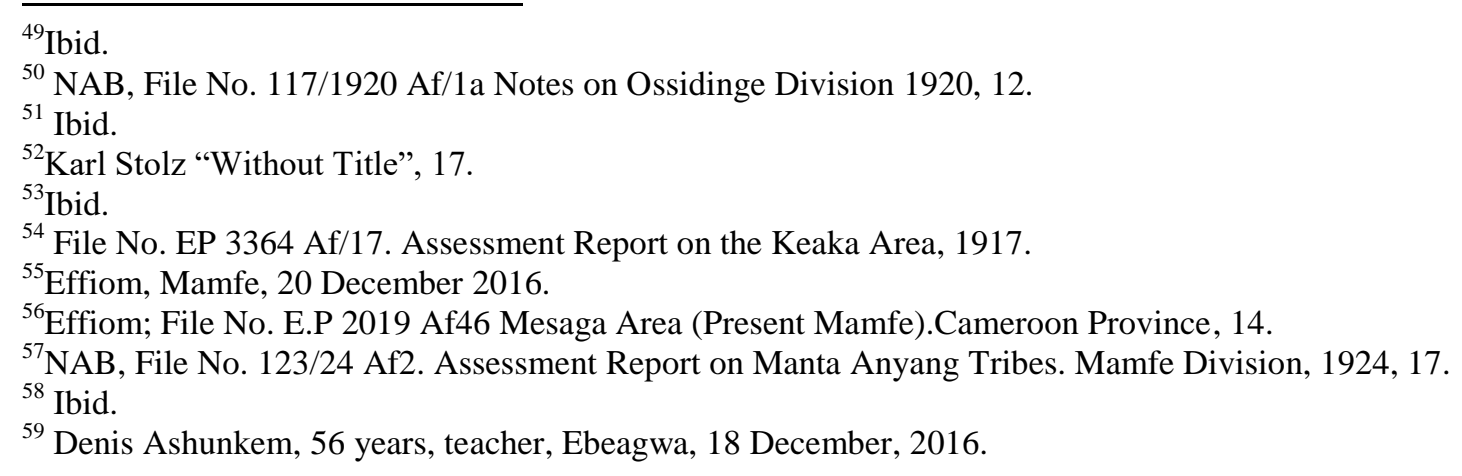


He is alleged to have fled to Mabum in gguti $^{60}$ where he remained and spent the rest of his life. ${ }^{61}$ Even though there is some discrepancy over where Ashu Nkem settled after his failed trip, it is clear that he took advantage of his closeness to the Germans to exploit his own people.

In Obang, some young men from the neighbouring villages of Akak, Arsibong and Okoroba raided the village and collected money, plantain, fowls and goats as taxes meant for the Germans. The dubious activities of these former German collaborators in Obang were varied and mostly took place between 1915 and $1916 .^{62}$ The vast nature of Obang which is approximately 240 square miles with a population of 2,212 facilitated the atrocious venture of these phony German devotees. ${ }^{63}$ In 1915 , a group of young men from Akak putting on red caps which indicated their attachment or closeness to the Germans raided Obang as German tax collectors and collected money and livestock. ${ }^{64}$ They made the people of Obang to believe that their masters, the Germans who sent them were resident somewhere before Mabum. In some of the raids they collected about nine Marks, fowls and goats. ${ }^{65}$ Some of them pretended to speak German at the time of their operation to prove to the people that they were actually working for the German colonial administration. ${ }^{66}$ Reacting to this malpractice which was an unusual phenomenon in Obang Emmanuel Bessong said:

The Obang clan was the first to be affected by the German operations. This was through the operations of the column which pushed up from the South and established a post at Tinto. The Clan Head which was my great grandfather was made responsible for the supply of labour and food for the German. This loyalty towards the Germans was what made them to be victims of the fake assistants who were simply enriching themselves. This tendency which was common in Obang should not be looked at from the stand point of fear by the people but as loyalty to the Germans. ${ }^{67}$

The polity of Obang was among the few in Ossidinge which had fake German devotees who took advantage of their relationship with the Germans to exploit the people. ${ }^{68}$ In July 1915, some former German carriers and errand boys from Bera constituted a team and arrogated to themselves the right to control the German warehouse which had a large stock of rubber and palm kernel. Some of them tried to sell the products, but, the war situation did not render the operation fluid. However, a few ferried produce to Ekok where it was sold. The remaining rubber at the factory side was taken over by the British government in $1916 .{ }^{69}$ The rubber lumps which were already in bad state were transported to Kumba through Nguti. As for the few bags of kernels that the "phony heroes" could not protect, they were looted by the villagers who had just learned that the Germans had been defeated in the war and were running for safety to Spanish Guinea. ${ }^{70}$

In Ossing, a returning "German soldier" called Batey Tabot seized the wife of a young man who had paid the dowry. ${ }^{71} \mathrm{He}$ did not provide as much as the young man had earlier given but, the family of the young girl, for the sake of prestige and fear of harassment, handed over their daughter to the "German soldier". ${ }^{72}$ This particular incident left the friends of the young man fuming and they pressured the

\footnotetext{
${ }^{60}$ Other sources hold that Ashu Nkem who escaped death after an unsuccessful trip to his native Ebeagwa fled to Kokobouma. $^{60}$

${ }^{61}$ NAB, File No. 117/1920 Af/a Notes on Ossidinge Division 1920, 7.

${ }^{62}$ NAB, File No. 1470/1925 Af52 Assessment Report on Obang- Balundu Districts. Mamfe Division 1925, $17-$ 18.

${ }^{63}$ NAB,File No. 28/1926 Af43. Mesaga Area (Present Mamfe) Report attached to Assessment Report, 22.

64 Ibid.

${ }^{65}$ Ibid.

${ }^{66}$ Solomon Oben, 62 years, teacher, indigene of Obang, Buea, 20 February 2017. His grandfather Njock Sun Oben participated in the First World War as a carrier.

${ }^{67}$ Emmanuel Bessong, 56 years, Teacher, indigene of Obang, Buea, 19 February 2017. His Great grandfather was the Clan Head and an able German collaborator.

${ }^{68}$ Ibid., 22.

${ }^{69}$ Ibid., 23.

${ }^{70}$ E.G. Hawkes Worth, "Mesaga Village (Present Mamfe) and Trade during the Great War", in Original Record Book of the British, 21. Hawkes Worth was the A.D.O Bamenda Cameroons Province right up to 1927.

${ }^{71}$ Ibid.

${ }^{72}$ Francis Bessong, 59 years, teacher, Buea, 20 February 2017.
} 
"German soldier" who escaped to the Ngonaya area. The girl returned to the former husband. Incidents of such magnitude were common in Kekukisem, Ajamen, Agborkem-German and Ayukaba where the Germans had a strong attachment with the people. ${ }^{73}$ Similarly, in Ajaman, a German soldier called Ojong Otu also forced a young lady into his home meanwhile the bride wealth had not been completed. According to Stolz, the process of the payment of bride wealth had started before the said man left for the war at Nsanakang. ${ }^{74}$ After the war, he returned but did not complete the bride wealth but coerced the young lady into his home. When the young lady returned to his parent's house, it was realised that she has been defiled by the young man. ${ }^{75}$ The matter was reported to the Village Council and it was fixed for hearing but the "German soldier" refused to appear in front of the Village Council. The Nfam(Traditional high priest) was consulted and an injunction was placed at the door of the German soldier. A few days after, he escaped to Nigeria for sanctuary. ${ }^{76}$

In like manner, in Agborkem-German, two cases of forceful claim of brides were reported. ${ }^{77}$ It was unheard of in Ossidinge before the First World War that a man could lay claim over a woman when her bride wealth had not been completed. Even though in the pre-colonial era some children especially girls were preserved for some young men, the relationship was only concretised after the child had grown to maturity and all formalities fulfilled. But, the force of war ushered a new experience. A man called Ojong whose real function in the war on the side of the Germans was not known returned from the war and laid claim over a young girl whom he was told had been earmarked as the wife. ${ }^{78} \mathrm{He}$ insisted the wife be given despite the fact that the bride wealth had not been paid. He was suspicious that the family will let the woman go since he was not ready to pay the bride wealth. It is said that Ojong joined the war in order to raise money for the dowry. ${ }^{79}$ But, like most young men who fought the war, he was frustrated after it. The tobacco he brought was very small to raise the dowry. $\mathrm{He}$ therefore decided to use his "authority" as a "German soldier" to pressurise the family of the young girl. His attempts failed and the disillusioned Ojong fled to the coast. A parallel situation also occurred in Ayukaba but the purported German soldier did not succeed to forcefully take the young woman ${ }^{80} \mathrm{~A}$ few cases of rape were also reported in Osselle, Eshobi and Nfainchang in which "phony German soldiers" used force to abuse young girls. ${ }^{81}$

According to Warnier, the potential power to be gained by assuming a position within the colonial machinery was attractive to many who sought this opportunity without actually having obtained that position. ${ }^{82}$ Warnier drew attention to the cadets, young male bachelors, who formed armed groups called Tapenta in the Grassfields, wearing red caps just like the German soldiers, pressing for food and women, while shouting in pidgin "lef mi, mi bi big boy, mi bi Tapentaboy" ${ }^{83}$ These "big boys" did not only adopt German dress, but also their language which they did not even master well. ${ }^{84}$

To stop these callous social abuses and phony heroism, a decree was passed by the British colonial administration in November 1916 that forbade all illegitimate use of German military uniforms that had previously been for sale in traders' shops. This mal practice which was a force that came into being during the war in Ossidinge was also witnessed in other places in Cameroon. Some of those who legitimately held positions in the German colonial machinery as soldiers, clerks, interpreters and

\footnotetext{
${ }^{73}$ Ibid.

${ }^{74}$ Paulin Stolz, "Without Title", 33.

75 Ibid.

${ }^{76}$ Ibid., 17; What became of him in Ajaman still remains a mystery.

${ }^{77}$ NAB, File No. 1474/1927 Af81 Keaka Assessment Report 1927, 22.

78 Ibid.

${ }^{79}$ Cletus Ojong Ako, 62 years, retired teacher, 18 December 2016.

${ }^{80}$ Interview cited in Michels, Imagined Power Contested, 296.

${ }^{81}$ Stolz, Without Title, 24.

82 Jean-Pierre Warnier, "Rebellion, Defection and the Position of Male Cadets: A Neglected Category". In Fowler and Zeitlyn, African Crossroads: Intersection between History and Anthropology in Cameroon (Oxford: Berghahn Books, 1996), 115-124.

${ }^{83}$ Michels. Imagined Power Contested; Loosely translated into the English Language as allow me, I am a big boy, I am an interpreter boy.

${ }^{84}$ Missionary Spellenberg 1914 cited in Warnier, "Rebellion, Defection and the Position of Male Cadets", 117; Pidgin was introduced here by German colonialism. Tapenter being a vulgarisation of "interpreter". For more information, see Warnier "Rebellion, Defection, 196.
} 
messengers were acting as if the Germans were still in control ${ }^{85}$ By the end of the war, the whitemans' dress had become a sign of power, and the collaborators of the Germans tried to obtain them as a means of wielding power over their fellow kinsmen. ${ }^{86}$

The bogus appropriation of power was not only perpetrated by "German soldiers". Some Ossidinge indigenes who took part in the war as soldiers in support of the British were also involved. However, the number of ex- British soldiers who exploited their association with British power was insignificant when compared to those of ex-German soldiers. ${ }^{87}$ The case of Tabong Nchong an ex-British soldier is very indicative. Before the British reached Ossidinge in 1916, he used his status as "British soldier" to extort money from the people. He made the people to believe that the British were on their way to Bakebe and that he had been assigned to collect money which will enable the British to open a station in Bakebe. He also told his people that the British insisted that all payments must be made in cash. ${ }^{88}$ This fake news was welcomed because, the people of Bakebe were eager to host the British as a show- up to the people of Tinto who used the presence of the Germans in their vicinity as a sign of superiority over them. ${ }^{89}$ George Kima described Tabong Nchong's malicious scheme in the following words:

TabongNchong was one of the very rare indigene of Bakebe who fought the First World War on the side of the British. Before leaving for the war, Tabong Nchong was aware that the people of Bakebe had deep seated hatred for the people of Tinto because of their provocative insults, which made them looked substandard. He took advantage of the situation to extract money from his people. On the days he did the collection, he dressed in white and had a list with him on which he scribbled what he alone could read. My father told me that the amount of money he took from the people could be estimated at more than 50 Marks. This was much money that was extorted from the villagers whose finances dwindled because of the war. His dubious practice was brought to an end when some British messengers in Mamfe learned of it and reported to the British authorities. He was arrested and taken to Mamfe. ${ }^{90}$

It is perceptible that the war was a force that in some surroundings, led to chaos, and paved the way for extortionist to make use of the people financially.

Correspondingly, in Ejwengang, Egbe Ntoh who participated in the First World War as a British soldier returned to the village in 1916 and decided to use his position as an ex-British soldier to impress himself on the Village Council. It is cardinal to state that to become a member of the Ejwengang Village Council, the concerned must be unanimously approved by the old members. ${ }^{91}$ But, after the war, Egbe Ntoh as an ex-British soldier and on his own accord arrogated powers to himself and decided to take a seat in a Village Council meeting. When the regular members saw him they protested, but, he presented a document that the British gave him with the right to sit in any village meeting. ${ }^{92}$ Suspicious of the document, the legitimate members of the Council used force to evict him. In retaliation, Ntoh went to his house and brought a gun and the commotion and effect of his action was described by Ashu Agbor in the following words: "My father told us that when the members of the Village Council saw him coming they escaped and left the food and drinks. After some negotiations the elders of the village asked him to fulfil the necessary conditions for membership which he did and he was admitted into the Ejwengang village Council". ${ }^{93}$

\section{CONCLUSION}

World War I was a drive that altered some aged-old practices in Ossidinge. It was very instrumental in re-defining roles which had earlier been established on gender lines. The conscription of male folks for war forced women to take up functions which were reserved for men. The war made women to be

\footnotetext{
${ }^{85}$ Egemene Ojong Ayem, 82 years, farmer, interview by Etamba, Nsanaragati, 18 December 2016.

${ }^{86}$ Idem.

${ }^{87}$ Maxwell TabongKima, 77 years, Bakebe, 29 November 2016.

${ }^{88} \mathrm{Ibid}$

${ }^{89}$ Ibid

${ }^{90}$ George Kima, 79 years, retired health worker, Bakebe, 29 November 2016

${ }^{91}$ Vincent Ashu, 63 years, retired teacher, Mamfe, 17 December 2016.

${ }^{92}$ Idem

${ }^{93}$ AshuAgbor, 59 years, Tailor, 17 December 2016.
}

International Journal of History and Cultural Studies (IJHCS) 
actively involved in the palm oil industry; they became the new custodian of the family treasury. By 1920, there were many women associations in Ossidinge with a major objective to empower the women. On the other hand, the Ossidinge phase of the war introduced some hysteric moments associated with the emergence of some phony war veterans who used every opportunity to assert their authority for economic, social and political gains. Some indigenes who took part in the war in support of the Germans and the British arrogated powers for financial extortionists' motives. Others saw it as a vent to surreptitiously gain entry into some strategic secret societies so as to exert influence over traditional decision making process. Approached from any angle, the war phase in Ossidinge provided categories of rippling effects which significantly altered the status quo and produced a new eclectic socio-economic and political society in the group of villages that made up the Ossidinge District in German Kamerun.

\section{REFERENCES}

[1] Bond, Edmond. "The Conquest of Cameroon" Contemporary Review- 109 (1916): 620-27.

[2] Cawston, Sir Joseph, \& Sons Limited.The War of 1914-1916. The Belgian Campaigns, In the Cameroons and in German East Africa London: Free press, 1917.

[3] Crowder, Michael. "The First World War and its Consequences" in Adu Boahen.ed. General History of Africa,Vol III: Africa Under Colonial Domination 1880-1935. California: Heinemann, 1985.

[4] Eyongetah, Tambi M., Brain Robert and Palmer Robin, A History of Cameroon.London: Longman, 1987.

[5] Etchu, Tarkang Victor. "Politics and Power in the Ejagham Clan of Manyu Division. The Case of the Ngonaya People, 1910- 1984" (Post Graduate Teachers Diploma, DI.P.E.S.II), Dissertation, University of Yaounde I, 1999.

[6] Michels, Stephanie. Imagined Power Contested: Germans and Africans in the Upper Cross River Area of Cameroon 1887-1915. Koln: Transaction Publishers, 2004.

[7] Moberly, F. J. Military Operations, Togoland and the Cameroons, 1914-1916 Uckfield East. Sussex: The Naval and Military Press, 2004.

[8] Stevenson, David. 1914-1918: The History of the First World War. London: Penguin Books, 2005.

[9] Tabe, Kennedy Eyong. "Kamerunian Participation in the First World War 1914-1916." MA Thesis in History, University of Buea, 2001.

[10] Tabe J.T. "Chieftaincy Succession in the Banyang and Ejagham Tribes of Manyu Division Cameroon, 1961-2002." Diplomed'Etudes Approfondies in History, University of Yaoundé, 2007.

[11] Tabi, Paulette. "La Premiere Guerre Mondiale: Le Cas Du Cameroun 1914- 1922 D.E.S Dissertation, University of Yaounde, 1978.

[12] Warnier, Jean-Pierre. "Rebellion, Defection and the Position of Male Cadets: A Neglected Category". In Fowler, Ian. And Zeitlyn, David. African Crossroads: Intersection between History and archaeology in Cameroon. Oxford: Berghahn Books, 1996: 115-124.

[13] Weladji, C. "The Cameroon-Nigeria Border 1914 and after" in ABBIA. No. 38-39-40 (May 1982): 213.

[14] Yearwood, Peter J. "In a Casual Way with a Blue Pencil: British Policy and the Partition of Kamerun, 1914-1919" Canadian Journal of African Studies. Vol. 27 No. 2, 1993, 218-244.

\section{National Archives, Buea (NAB)}

[15] NAB, File No. 117/1920 Af/1a Notes on Ossidinge Division 1920.

[16] File No. E.P 3364 Af/17. Assessment Report on the Keaka Area, 1917.

[17] File No. E. P 2019 Af46 Mesaga Area (Present Mamfe). Cameroon Province.

[18] NAB, File No. 123/24 Af2. Assessment Report on Manta Anyang Tribes. Mamfe Division, 1924.

[19] NAB, File No. 117/1920 Af/a Notes on Ossidinge Division 1920.

[20] NAB, File No. 1470/1925 Af52 Assessment Report on Obang- Balundu Districts. Mamfe Division 1925.

[21] NAB,File No. 28/1926 Af43. Mesaga Area (Present Mamfe) Report attached to Assessment Report

[22] NAB, E.G. Hawkes Worth, "Mesaga Village (Present Mamfe) and Trade during the Great War", in Original Record Book of the British.

[23] NAB, File No. 1474/1927 Af81 Keaka Assessment Report 1927.

\section{Bundersarchiv Berlin,BAB (National Archives Berlin)}

[24] BAB, R1001/4313:81-83,Expeditionen Ossidinge. 
Gender Redistribution of Roles and Phony Heroes in Ossidinge (Cameroon) during the First World War, 1914- 1916

Archives of the Basel Mission (ABM)

[25] ABM, KarlStolz. 01: 06: 1915, “Without Title”File No. E-2-14.

[26] ABM, Karl Stolz.JahresberichtOssing, 1914.File No.E-2-14

[27] ABM, PaulineStolz."Without Title”, File No.E-2-15.

[28] ABM, Pauline Stolz. "Manuscripts On My Long Stay in Besongabang" File No. E-2-15

\section{Interviews}

[29] Agbor, Ashu. 59 years, tailor, Mamfe, 17 December 2016.

[30] Ako, Ojong Cletus. 62 years, retired teacher, Mamfe, 18 December 2016.

[31] Ashu,Vincent. 63 years, retired teacher, Mamfe, 17 December 2016.

[32] Ashunkem, Denis. 56 years, teacher, Ebeagwa, 18 Decemnber, 2016.

[33] Ayuk, Emilia. 65 years, farmer, Ewelle, 18 December 2016.

[34] Ayukeba, Mansfeld. 80 years, retired trader, Mamfe ,13 December 2016.

[35] Bessong, Francis. 59 years, teacher, Buea, 20 February 2017.

[36] Bessong, Emmanuel. 56 years, Teacher, indigene of Obang, Buea, 19 February 2017.

[37] Effiom, Warnier, N. O. 94 years, Former Grand Chancellor of the National Order of Valour and erstwhile Speaker of the West Cameroon House of Assembly, Mamfe, 20 December 2016.

[38] Egemene, OjongAyem. 82 years, farmer, Nsanaragati, 18 December 2016.

[39] Kima, George. 79 years, retired health worker, Bakebe, 29 November 2016.

[40] Mangyep, Cecilia. 64 years, teacher, Mamfe, 19 December 2016.

[41] Oben, Solomon. 62 years, teacher, indigene of Obang, Buea, 20 February 2017.

[42] Ojong, Ako Cletus. 62 years, retired teacher, Mamfe, 18 December 2016.

[43] TabeTando, NdipNso, HRH. 67 years, Traditional ruler of Bachuo-Ntai, Douala, 11 January 2018.

[44] Tabong, Kima Maxwell. 77 years, Bakebe, 29 November 2016.

\section{AUTHORS' BIOGRAPHY}

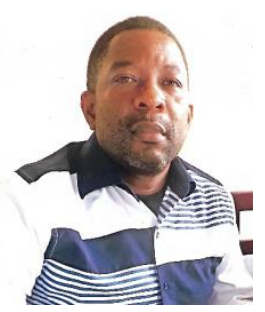

Thomas Etamba Eta is a PhD candidate in the Department of History and Archaeology at the Faculty of Arts, The University of Bamenda in Cameroon. He has been teaching history in Secondary and High schools in Cameroon for the past twenty-two years. He is an Assistant Chief Examiner for Advanced Level History at the Cameroon General Certificate of Examination Board. He is a bona fide member of the Cameroon History Society and the South West Association of History Teachers. His teaching and research interests is on political and social history, historiography, international relations and cooperation.

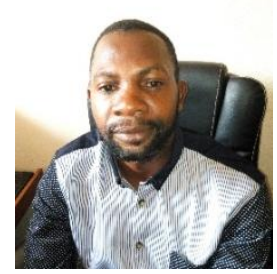

Dr. Nixon Kahjum Takor is currently an Associate Professor of History and Chair of the Department of History and Archaeology at the Faculty of Arts, The University of Bamenda in Cameroon. He is a member of the Business History Congress and the Cameroon History Society. His teaching and research interests over the years has centered on aspects of economic and social history, public history, didactics of history, historiography and historical research methods.

Citation: Thomas Etamba Eta, Dr. Nixon Kahjum Takor. "Gender Redistribution of Roles and Phony Heroes in Ossidinge (Cameroon) during the First World War, 1914- 1916”. International Journal of History and Cultural Studies (IJHCS). vol 5, no. 1, 2018, pp. 36-46. doi: DOI: http://dx.doi.org/ 10.20431/24547654.0501004.

Copyright: (C) 2019 Authors. This is an open-access article distributed under the terms of the Creative Commons Attribution License, which permits unrestricted use, distribution, and reproduction in any medium, provided the original author and source are credited. 